\title{
Organiskās sintēzes institūts, pretgripas preparāts remantadīns un tā izgudrotājs Jānis Polis
}

\author{
(LZA Senāta priekšsēdētāja runa Organiskās sintēzes institūta \\ zinātniskās padomes svinīgajā sēdē 2009. gada 6. februārī medaļu \\ piešķiršanas ceremonijā)
}

\section{Jānis Stradiņš}

2009. gads Latvijā ienāk ar finanšu krīzi un saimniecisko depresiju, ko izraisijušsas l̦oti nelabvēlīga iekšējo un ārējo apstākḷ sakritība un Latvijas politiskās elites kḷūmes, stratēgiski aplama rīcỉba daudzu gadu garumā. Šādā situācijā var gausties, bet var tomēr meklēt pozitīvus piemērus kā balstu cerībai un rīcībai nākotnes labad. Šodien Latvijā, Rīgā, šajā vietā mums ir laime būt klāt paraugstundā nelielos zinātnes svroti, Pasaules Intelektuālā ìpašuma organizācija (WIPO) Ženēvā 2008. gada decembrī pieškīrusi divas balvas (WIPO Award) - pirmo Latvijas Organiskās sintēzes institūtam kā inovatī-

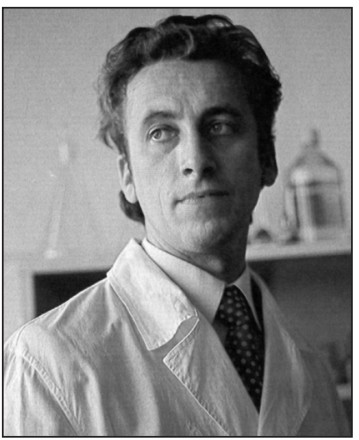
vam uzñēmumam (Innovative Enterprise) un otru balvu - zelta medalıu izcilam izgudrotājam ilggadējam institūta darbiniekam Dr. Jānim Polim par izgudrojumiem medicinnas ķ̄imijā, un tieši par pretvīrusu preparāta remantadīna izgudrošanu un ieviešanu.

Mēs bieži uzsveram, ka Latvijai, tāpat kā somiem, nepieciešama sava NOKIA, lai atdzīvinātu arī pie mums inovatīvu ražošanu, paceltu tautsaimniecību. Protams, Somijas tautsaimniecība nebūt nebalstās uz NOKIA vien; ne tikai NOKIA izvedusi šo ziemeḷvalsti no stinguma pēc PSRS un daudzinātās "finlandizācijas" sabrukuma. To izdarīt lāvis vesels saimniecisku, kultūras, ètikas komponentu 


\section{J. Stradiň̌}

kopums. Postkomunisma Latvijā ir savijies sarežğîtu momentu komplekss, kas kavējis mūsu valsts attīstîbu. Vecā rūpnieciskā ražošana ir lielā mērā sabrukusi, rūpniecỉba dod vairs tikai $12 \%$ nacionālā kopprodukta. Savukārt ne vairāk kā 17\% ražošanas produktu var uzskatìt par inovatīviem.

Taču bēdīgajā realitātē vismaz viena pašu NOKIA mums tomēr ir, un jau labi sen. Tas, manuprāt, ir Latvijas Organiskās sintēzes institūts (OSI), ap kuru jau 50 gadu ir grupējušies zinātnieki, izgudrotāji, veidojušies inovatīvi ražošanas uzṇēmumi, kur tapuši jauni ārstniecības līdzekḷi, kas savu vietu izcinnijuši ne tikai lokālā mērogā, bet arī visā Eirāzijas telpā un pat plašākā pasaulē [1-3]. OSI pastāvēšana ir bijusi garants Latvijas farmācijas rūpniecības (firmu "Grindekss" un "Olainfarm") tālākpastāvēšanai neatkarības apstākḷıs, - tā ir tā inovatīvas ražošanas dạ̦a, kas Latvijā joprojām attīstās. Ne velti nākotnes stratēgiijas prognozēs farmācijas rūpniecỉbu parasti min kā pirmo no prioritātēm vai vismaz sarakstā pašā augšgalā.

Organiskās sintēzes institūts ir dibināts 1957. gada janvārī, un šodien mums ar pateicību jāpiemin tā dibinātājs akadēmikis Solomons Hillers (1915-1975), kas institūtu vadijis pirmos 18 gadus (1957-1975) [4, 5]. Nepārspēts zinātnes organizators, cilvēks ar stratēgisku domāšanu, dinamiska personība - no paša sākuma viņš vadīja savu institūtu kā inovatīvu uzṇēmumu, kaut arī tolaik termins 'inovatīvs' netika lietots. Taču sociālistiskās plānsaimniecības apstākḷ,os, Hruščova un Brežn,eva laikos institūts patiešām bija inovatīvs, konkurētspējīgs. Hilleram piemita īpašas spējas saskatīt pašu aktuālāko, prasmīgi izmantot konjunktūru. Var piekrist pazīstamā Maskavas k̦īmiḳa Alekseja Kosta replikai, ka citos apstākḷos Hillers būtu bijis veiksmīgs kapitālists - viņš pielāgoja biznesa principus pat sastingušajai PSRS plānsaimniecības videi.

Tas bija Padomju Savienības ietvaros neparasts, progresīvi organizēts pētniecības centrs, kurā vienojās fundamentālie pētījumi ar jaunu (bieži gan pēc ārzemju paraugiem resintezētu) medikamentu izstrādi un jaunu zinātnieku piesaisti. Tas bija komplekss institūts, kur līdzās k̦īmijas laboratorijām (sintēzei, analīzei, struktūrpētniecibai) bija arī bioloğisko un medicīnisko pētỉjumu nodal̦a un eksperimentālā rūpnīca. Tas 35 gadus ḷāva īstenot pilnu medikamenta tapšanas ciklu - no sākotnējās idejas, aktīvās vielas sintēzes laboratorijā līdz pusrūpnieciskā vai pat rūpnieciskā produkta ražošanai.

OSI ir tapuši vismaz 65 medikamenti un lauksaimniecības preparāti, no tiem 17 orig̣ināli medikamenti vēža, baktēriju un vīrusu infekciju, kardiovaskulāro slimību ārstēšanai, psihofarmakoloǵijas preparāti. Toreizējā PSRS 20. gs. 70.-80. gados katrs ceturtais oriǵinālais "padomju preparāts" tika radīts Rīgā, OSI, plašajam lielvalsts zālu tirgum. Institūts ik gadu guva 8-10 patentu un pieteica 25-30 PSRS autorapliecību. Tas plaši sadarbojās ar simtiem medicīnas centriem PSRS, arī ar Japānas, Francijas, Somijas, Zviedrijas, VFR, ASV zāļu ražotājfirmām, eksportēja oriǵinālo pretvēža preparātu ftorafūru uz Japānu un citām valstīm.

Pēc 1991. gada šis komplekss lielā mērā izira. Eksperimentālā rūpnīca kḷuva par neatkarīgu firmu "Grindekss", institūtā vairs nebija vivārija, tika sašaurināti vai 
pārtraukti biologiski medicīniskie pētījumi, arī molekulārā biologiija (E. Grēns) nodalìjās atsevišķā centrā. Taču iespēju robežās Hillera aizsāktās tradīcijas tika turpinātas, īpaši akadēmiķa Ivara Kalviņa vadībā. Izveidojās kopprojekti ar 11 ārzemju farmaceitiskajām firmām. Kopš 1995. gada institūts ir saṇēmis 340 patentus, turklāt pēdējos piecos gados kopā ar ārzemju partneriem - 64 patentus. "Grindeksa" pamatprodukts pašreiz ir institūtā izstrādātais mildronāts (arī pretvēža preparāts ftorafūrs). Arī "Olainfarm" asortimentā ir ḷoti daudz OSI izstrādāto medikamentu, to skaitā remantadīns.

Pašreiz OSI ir vadošais medikamentu izstrādes centrs Baltijas valstīs, kas sadarbojas daudzos fundamentālās un lietišḳās pētniecības projektos ar Latvijas zāḷu ražotājiem, ārvalstu farmācijas kompānijām un universitātēm. Tagadējais direktors I. Kalviņš efektīivi turpina S. Hillera aizsākto stratēégiju [6].

No pēdējās desmitgades pētnieciskajiem sasniegumiem minama OSI līdzdalība pirmā Alcheimera slimības ārstēšanas preparāta memantina izstrādē. Sadarbībā ar tiem pašiem VFR partneriem radīts nākamās paaudzes preparāts (2003), kas pašreiz atrodas klīnisko pētījumu otrā fāzē Rietumeiropā un ASV. Kopā ar Lielbritānijas un Dānijas partneriem atklāts jauns potenciāls pretvēža medikaments - belinstats, kas patlaban (2007) atrodas 2. un 3. klīnisko pētījumu fāzē Eiropā un ASV. Atklāta arī jauna organisko vielu klase ar izteiktām potencēm aizkuṇga dziedzera audzēju terapijā. Minēto jauno preparātu galvenie autori ir akadēmiḳis I. Kalviņš, E. Loža, A. Jirgensons, V. Andrianovs, I. Šestakova u. c. Bez tam ir vairākas citas potenciālas izstrādes, kas aizsargātas ar patentiem un kuras varētu komercializēt drīzā nākotnē [7].

Jāatzīmē, ka jau agrāk OSI darbinieki ir izpelnijjušies WIPO medaļas - Ivars Kalviņš 2005. gadā (zelta medaļa) un Gunārs Duburs 2006. gadā. Nu viniem pievienojas Valsts emeritētais zinātnieks LZA goda doktors Jānis Polis, ilggadējs institūta darbinieks (līdz 1997. gadam) [8, 9]. Tas zināmā mērā ir novēlots leǵendārā izgudrotāja suminājums viņa 70. dzimšanas dienā, kas nepamanīta aizritējusi 2008. gada 25. jūnijā. Jānis Polis ir plaši pazīstams kā pretgripas preparāta remantadina autors.

Remantadīnu varētu dēvēt par vienu no trim valiiem, uz kuriem balstijies OSI un Latvijas ḳīmiski farmaceitiskās zinātnes prestižs. Protams, ir bijuši gan nitrofurāna rindas medikamenti, gan dihidropiridīni, gan peptīdu preparāti un vēl citi, tomēr plašāku ievērību guvuši trīs medikamenti: pretvēža preparāts ftorafūrs (tegafürs), kardioprotektors un imūnprotektors mildronāts un antivirālais medikaments remantadīns. Pie šo preparātu šūpuḷa ir stāvējis vēl Solomons Hillers sava mūža beigu cēlienā. Viņš uzskatāms par ftorafūra galveno autoru, taču kā mildronāta pamatautors noteikti atzīstams Ivars Kalviņš, kamēr remantadīna tapšanā pamatnopelni pieder Jānim Polim. Nosaukto preparātu skaitā remantadīns, iespējams, ir populārākais, jo tas ir preparāts ilgdzīvotājs, un ik ziemu gripas sezonā tas aktualizējas atkal un atkal, it îpaši šogad - gan pie mums, gan daudzās citās valstīs. 


\section{J. Stradinš}

Par mildronātu un ftorafūru rakstīts pietiekami daudz, par tiem samērā plaša informācija rodama OSI 50 gadu jubilejas grāmatā, kamēr adamantāna rindas preparātu tapšana un remantadīna ḳīmijas vēsture OSI izgaismota mazāk. Tā nesaraujami saistās ar Jāṇa Poḷa k̦imiķ̣a darbỉbu un radošo personỉbu.

Jānis Polis institūtā strādāja no 1961. līdz 1997. gadam. Pēc Rìgas Politehniskā institūta Ķīmijas fakultātes absolvēšanas viņš bija norīkots uz Lìvānu spirta brūzi par inženieri, bet sacīja, ka nedzerot, un tad klātesošais Hillers piedāvāja darbu OSI. Tā Polis kḷuva vispirms par Hillera aspirantu (kādu brīdi formāli skaitījās mans aspirants un visu laiku intensīvi sadarbojās ar mūsu fizikāli organiskās ḳ̂̄mijas laboratoriju), vēlāk par vecāko inženieri un vecāko zinātnisko līdzstrādnieku (1966-1975). Pēc Hillera nāves aizstāvēja savu k̦īmijas zinātņu kandidāta disertāciju (1975), tad bija institūta Biologisko pētījumu nodaḷas vadītājs (1975-1982; tajā bija trīs laboratorijas un vivārijs) un pēdīgi - par vecāko zinātnisko līdzstrādnieku (1983-1993). Pēdējos darba gados institūtā bija asistents, jo ilgu laiku atteicās pielīdzināt savu kīmijas zinātṇu kandidāta grādu Latvijas Republikas k̦īmijas doktora grādam (vēlāk gan to izdarīja). Viṇš strādāja M. Līdakas, G. Zelčāna un I. Kalviņa laboratorijās. Jānis allaž strādājis "pārcilvēcīgā" režīmā, pa 12 stundām dienā, ar degsmi, bet tad uz laiku varēja arī no ķīmiḳa darba izslēgties vispār, nodoties citām nodarbēm.

Jau studiju gados J. Polis bija devies uz Kazahstānu apgūt neskartās zemes, par ko apbalvots ar attiecīgu PSRS medalı. Ar humoru viņš tur atceras savu tikšanos ar Leonīdu Brežñevu, kas toreiz bija Kazahijas KP pirmais sekretārs, vēl samērā mazpazīstams politiķis. Neskarto zemju apguvēji naktī uzcelti pēc trauksmes signāla un Polis sēdies uz traktora ar ieslēgtām ugunīm, lai kolonnā braucot imitētu darbību - itin kā nakts tumsā dotos uz aršanu. Faktiski ši kolonna salutēja sekretāram Brežņevam, ko tas arī piemin savos kuriozajos memuāros. Savā ḳīmiķa darbā Jānis Polis arī bija romantiķis, taču darbojās bez izrādī̌anās. Labi atceros viņa darbošanos arī fizikāli organiskās ḳīmijas laboratorijā, pie E. Liepiṇa - viņš bija viens no pirmajiem k̦īmiķiem organiķiem, kas reāli uzṇēma un atšifrēja paša sintezēto savienojumu kodolmagnētiskos spektrus. Atceros daudzās sarunas manā kabinetā gan par gūtajiem rezultātiem, gan par visdažādākajām dzives problēmām. Taču tas viss bija vēlāk - pēc pamatīgas iestrādāšanās adamatāna ḳīmijā.

Aspirantūras laikā J. Polis bija saslimis ar tuberkulozi un ārstējās sanatorijā, kad 1964. gada oktobrī institūtā ar lekciju viesojās Kijevas Politehniskā institūta profesors Fjodors Stepanovs, adamantāna k̦īmijas celmlauzis Padomju Savienībā. Adamantāns ir og̣̣ūdeṇradis ar ḷoti simetrisku molekulas struktūru: desmit oglekḷa atomi tajā izvietoti tāpat kā dimanta kristāliskajā režǵìi (tikai brīvas saites pie oglekḷ atomiem aizņem ūdeņraža atomi). Šo savienojumu vispirms čehu kīimiḳis S. Landa izdalīja no naftas, vēlāk ieguva sintētiski. Sākumā domāja, ka adamantāns kā jau oglūueņradis ir ķīmiski inerts. Taču 1963. gadā tā atvasinājumiem konstatēja izteiktu pretvīrusu aktivitāti, un drīz vien arì padomju informatīvajā biḷetenā "Za Rubežom" parādījās ziṇa par ASV firmas Dupont preparātu simetrelu 
(1-aminoadamantānu) jeb amantadīnu, ko ieteica kā preparātu A vīrusu izraisītas gripas profilaksei.

Sākumā bija domāts, ka PSRS varētu iepirkt amerikāṇu preparātu, taču Hillers apsteidza notikumu gaitu. 1965. gada 9. februārī notika pirmā Hillera un Poḷa telefona saruna par jauno pretgripas preparātu, un drīz S. Hillers savu aspirantu komandēja uz Kijevu specializēties adamantāna kiimijā pie F. Stepanova (šie un turpmākie dati no J. Stradiņa intervijas ar J. Poli 2009. g. 27 janvārī un 5. februārī).

Drīz vien Rīgā tika resintezēts amerikāṇu simetrels, kam te deva nosaukumu midantāns. Šo preparātu un vēlāk dažus tā līdziniekus sintezēja Jānis Polis ar savām palīdzēm Ilzi Gravu, Baibu Ragueli un Birutu Vilni. Savienojumu antivirālo aktivitāti izpētìja Mūza Indulēna ar līdzstrādniekiem Augusta Kirhenšteina Mikrobioloǵijas institūtā, kur šos pētījumus īpaši atbalstija institūta direktore Rita Kukaine (organisko savienojumu antivirālās aktivitātes pētījumi Latvijā pirms tam netika veikti, bija jāapgūst visas attiecīgās metodikas). Būtiski arī tas, ka šai jomai reālu atbalstu sniedza arī izcilais virusologs L,eṇina prēmijas laureāts Anatolijs Smorodincevs (1901-1986), kurš organizejja aktīvo savienojumu klīniski epidemiologiskās pārbaudes. Kā jau sacìts, midantāns (amantadīns) nebija oriğināls preparāts, taču to ražoja Rīgā un plaši lietoja A vīrusa izraisītās gripas profilaksei. Tas saglabājis savu nozīmi kā pretparksionisma līdzeklis arī šodien "Olainfarm" ražojumu asortimentā un joprojām iekḷauts LR Zāḷu regiistrā.

Svarīgi bija izstrādāt līdzekli ne tikai gripas profilaksei, bet arī ārstēšanai. Un te nu Polis Dupont Nīderlandes patentos uzdūrās daudziem firmas patentēto adamantāna atvasinājumiem, sāka daudzus resintezēt pats un nodeva tos Mikrobiolog̣ijas institūtam virusolog̣iskām pārbaudēm. Plašajā formulu klāstā bija arī strukturāli tuvais midantāna analogs ( $\alpha$-metil-1-adamantilmetilaminns), ko amerikāṇu firma nodēvēja par rimantadīnu, taču kā reāls preparāts firmai vien zināmu apsvērumu dēḷ tas ASV ražots netika.

Pēc J. Poḷa sniegtajām ziņām, šìs vielas parauga pirmā elementanalīze Rīgā veikta 1969. gada 5 . novembrī, un jau 1969. gada 12 . decembrī iesniegta pirmā PSRS autorapliecība par remantadīna ražošanas paṇēmiena izstrādāšanu, bet 1970. gada 17. februārī tas nodots Indulēnai pārbaudēm. Izpētot šo ASV patentā jau pieminēto savienojumu, tika konstatēts, ka remantadīns ir daudz aktīvāks nekā midantāns, turklāt tam ir ne tikai profilaktiskas, bet arī terapeitiskas īpašỉbas, tas darbojas uz gripas vīrusa ačgārno transskriptāzi.

Vispirms jau savā OSI laboratorijā 1972. gadā pats Polis sintezēja pirmo medikamenta kilogramu, vienlaikus izstrādāja vielas ražošanas reglamentu Eksperimentālajai rūpnīcai, kas 1972. gadā nodrošināja jaunās vielas pirmos kilogramus plašākai klīniski epidemioloǵiskajai pārbaudei L̦eņingradā. Te izšķiroša nozīme bija jau minētajam PSRS Medicīnas Zinātṇu akadēmijas akadēmiḳim Anatolijam Smorodincevam, toreizējam Vissavienības Gripas institūta direktoram. Atgādināšu, ka Smorodincevs savulaik plašā klīniskā eksperimentā bija pārbaudījis 


\section{J. Stradiň̌}

Sebina dzīvo vakcīnu pret poliomielītu, kas l̦āva likvidēt PSRS poliomielītu kā epidēmiju, par ko saṇēma kopā ar M. Čumakovu L̦eṇina prēmiju 1963. gadā. Pēc tam Smorodincevs pats bija arī radījis pirmās vakcinas pret gripu, ērču encefalìtu, masalām. Taču atškirīibā no daudziem virusologiem, kas vienpusīgi iestājās par vakcināciju, Smorodincevs atbalstīja arī pretvïrusu ķīmisko vielu meklējumus. Turklāt viņš bija toreizējā PSRS Ministru Padomes priekšsēdētāja progresīvi domājošā Alekseja Kosigina ārsts un medicīniskais konsultants, kura kompetencē bija klīniski epidemioloǵisko masveida izmēǵinājumu īstenošana. Būtỉbā šis atbalsts un Rīgas un Ḷeṇingradas zinātnieku sadarbība lielā mērā izšḳīra remantadīna kā PSRS medicīnas praksē iekḷauta zāḷu līdzekḷa likteni.

Pirmais jaunā pretgripas līdzeḳ̣a nosaukums PSRS bija meradāns, ar šādu nosaukumu notika pārbaudes. Taču tieši Smorodincevs esot ieteicis nosaukumu 'remantadīns', kad preparātu 1975. gadā reǵistrēja PSRS Farmakoloǵijas komitejā. Smorodincevs arī ziṇoja par šo preparātu sava ASV brauciena laikā, detantes gaisotnē, un viņa ziņojums izraisīja Amerikā zināmu sensāciju plašā epidemiologiiskā materiāla un klīniski apstiprināto datu dēḷ. Iespējams, ka preparāta nosaukuma maiņa, tuvinot to ASV proponētajam rimantadīnam, notika šì brauciena ietekmē.

Tikām Hillers jau bija miris, arī Smorodincevs vairs nebija Gripas institūta direktors. Ar preparāta rūpniecisku ražošanu arī negāja tik viegli, daudzi Maskavas ierēdṇi bija pret to, cerot uz ASV preparāta importu un arī skaudỉbas dēl pret Rīgu. Tad Polis izšḳīās par pārdrošu soli Hillera garā. 1976. februārī PSKP XXV kongresa debatēs tika runāts par gripas epidēmiju izraisītajām darbaspēka zaudējuma problēmām PSRS rūpniecībā. Polis no institūta pēc darbadienas ap pusnakti devās uz Rīgas galveno pastu un nosūtija telegrammu tieši savam senajam paziņam PSKP generālsekretāram Leonīdam Brežņevam, ka Rīgā ir efektīvs preparāts pret gripu, bet esot grūtības to ieviest. Sākumā telegrammu negribēja pieṇemt, jo Polis to bija parakstījis kā institūta darbinieks, taču galu galā to nosūtỉja. Pēc tam kopā ar prof. Smorodincevu viṇi abi apstaigāja Maskavā vadošu instanču kabinetus, lai panāktu Vissavienības finansējumu jaunā preparāta ražošanai. Tā nu remantadīns bija zināmā mērā kḷuvis par politisku problēmu un, kā redzams, tā ieviešana pat padomju veselības aprūpes sistēmā nebija tik vienkārša.

Kā zināms, 1972. gadā Olainē tika dibināts jauns Vissavienības uzṇēmums tagadējais "Olainfarm", un viens no tā pirmajiem orig̣inālpreparātiem bija tieši remantadīns, ko sāka ražot 1976. gada rudenī - un jaunai gripas sezonai saražoja pirmos $485 \mathrm{~kg}$. Preparāta ražošanas tehnoloǵiju patentēja arī ārzemēs - ASV, Lielbritānijā, Belg̣ijā (1972), Indijā (1972), VFR (1979), arī Francijā, Japānā. Polim ar līdzautoriem pieder 8 ārzemju patenti un trīs PSRS autorapliecỉbas par remantadīnu; arī citur pasaulē (cik zināms, arī Ķīnā) preparātu ražo pēc Rìgā izstrādātām J. Poḷa tehnoloğijām $[9,10]$.

Tātad šogad (2009) aprit tieši 40 gadi kopš pirmās remantadīna ḳīmiskās sintēzes Rīgā, un 33 gadi kopš tā ražošanas sākšanas tagadējā "Olainfarm". Arī mūsdienās tas joprojām ir viens no šajā firmā ražotajiem pamatpreparātiem. To 
patērē Latvijā (ap 10-12\% ražošanas apjoma), eksportē uz Krieviju, Baltkrieviju, Kazahstānu, Bulgāriju, Lietuvu, Moldovu, Uzbekiju, Gruziju (J. Savicka sniegtie dati), arī uz Poliju un Čehiju. "Olainfarm" ražošanas apjoms ir 5,5 miljoni iepakojumu gadā (2008. gadā; 2004. gadā tas bija 1,7 milj. - pieprasījums audzis!), ik gadu eksporta vērtìba sniedzas daudzos miljonos latu. Tã arī ir viena no Latvijas intelektuālajām eksportprecēm, ko izmanto ne tikai pret A tipa gripas vīrusu, bet arī pret ērču encefalìta ierosinātāju. Tiesa, remantadīna cena arvien pieaug, un pašreiz iepakojuma cena aptiekās dažuviet sasniedz jau 8 latus [11].

Jānis Polis ir arī vairāku citu adamantāna rindas preparātu izgudrotājs (gludantāns, adapromīns), taču nozīmības un popularitātes ziņā remantadīnu neviens nav pārspējis, un citi preparāti šodien vairs arī nav zāḷu tirgū un medikamentu rokasgrāmatās. Izgudrotājs ir publicējis ap 90 zinātnisku rakstu, saṇēmis 36 autorapliecības, 15 ārzemju patentus. Viṇš ir bijis starp pašas pēdējās Latvijas PSR Valsts prēmijas laureātiem (1989), saṇēmis Grindeḷa medaḷu (1997) un LZA goda doktora grādu (1999). Bez tam institūts, gk. pateicoties J. Polim kopā ar Vissavienības Farmācijas ḳīmijas institūtu (ВНИХФИ) Maskavā 1976. gadā saṇēmis IV pakāpes PSRS Ministru Padomes prēmiju. Starp citu, tieši pētījumiem pretvīrusu preparātu meklējumos institūtam tajos gados jāpateicas par ḷoti dāsnu Vissavienības finansējumu, kas ḷāvis te attīstīt arī pētījumus bioorganiskajā kịmijā un molekulārbiolog̣ijā, sekmējis akadēmiķu E. Grēna un G. Čipēna pārstāvēto virzienu izvēršanos to agrīnajos attīstības posmos.

Tas viss it kā liecinātu par success story, veiksmes stāstu, taču izgudrotāja mūžs nebūt nav bijis rozēm kaisīts. Jāṇa Poḷa tēvs, atgriezies dzimtenē no angḷu gūsta, tika notiesāts uz 25 gadiem, un izgudrotājs skaitìjās represētā dēls (tēvu vēlāk reabilitēja). Hillers uzñēmās lielu atbildību, uzticēdams Polim atbildīgus darbus institūtā, bet Polis visus komunistiskā režìma gadus tā arī nedrīkstēja izbraukt uz ārzemēm (невыездной). Nodošanās zinātnei un izgudrotāja aktivitātēm bija viņa pašapliecināšanās veids, un jāuzteic institūts, kas šādu cilvēku atbalstijja. Taču paša impulsīvais, nereti neaprēķināmais raksturs sagādājis J. Polim daudz nepatikšanu un galu galā veicinājis viņa aiziešanu no institūta. Viṇa motivācija nekad nav bijusi strādāt naudas vai apbalvojumu dẹl un nekā viņš netika iekrājis.

Neparedzēti sarežğijumi radās ar dzīvokli, jo nelaimīgā kārtā Polis bija īēejis dzīvokli privātmājā, pie Āgenskalna tirgus, ko bija spiests atstāt. Cilvēks, kurš būtu cienīgs kḷūt par miljonāru, 20. gs. 90. gadu beigās uz vairākiem gadiem nokḷuva sociālās hierarhijas apakšstāvos, bez līdzekḷiem un bez mitekḷa. Par laimi, šis dzīves paradokss rada samērā pozitīvu risinājumu, pateicoties atbalsij plašsaziñas līdzekḷos (īpaši Latvijas Radio ar žurnālistes B. Šābertes ierosmi) un, es iedrīkstos atgādināt, arī Latvijas ZA atbalstam. 2000. gadā Rìgas Dome piešḳīra izgudrotājam ciešamu dzīvokli pilsētas sociālajā mājā Rāznas ielā, kuru Jānis Polis iekārtoja ar rūpību un mīlestîbu. Neilgi pirms tam viņš beidzot arī nostrificēja savu kandidāta grādu un varēja kḷūt par Valsts emeritēto zinātnieku, viṇam tika piešķirts LZA goda doktora nosaukums. 


\section{J. Stradinš}

Domāju, ka šis ir lıoti spilgts, ja ne Latvijā pats spilgtākais piemērs sabiedrības attieksmei pret izgudrotāja darbu. Ja ne remantadīns, par kuru ar tādu enerğiju un iedvesmu cīnijās Jānis Polis, nez vai viņa dzìves samezglojumi būtu nokārtojušies. Taču vai sabiedrībai pašai nebūtu - ātrāk un gludāk - jānovērtē izgudrotāja darbs, kura rezultāts tik daudziem un tik dažādās valstīs ir nesis atvieglinājumu no ciešanām, paglābis no bīstamās gripas?

Katrā ziņā šì diena ir izgudrotāja pelnīts vērtējums, un man ir liels prieks, ka esam tomēr mācījušies dot arī šo morālo gandarījumu krietnam ķīmiḳim un krietnam cilvēkam par viņa izcilo veikumu, arī par izpalīdzību kolēgiem daudzās grūtās situācijās. Jānis Polis pēc ilga pārtraukuma šodien atkal stājas ḳīmiķu sabiedrības priekšā, un tas ir labi. Šodien notiek "pazudušā dēla" atgriešanās dzimtajā institūtā, kaut uz pāris stundām - gandrīz vai Bībeles stāsta sižets. Apsveicu ZA Senāta vārdā OSI un Jāni Poli ar pelnītu starptautisku atzinību, novēlu gan institūtam, gan izgudrotājam jaunas veiksmes, veselību arī pašiem un visai mūsu sabiedrībai.

\section{Vēres}

1. Academy of Sciences of the Latvian SSR. Institute of Organic Synthesis. Basic and Applied Research. J.Stradiņš (Ed.) English and Russian. Moscow: Vneshtorgreklama, 1980. $107 \mathrm{p}$.

2. Latvijas Organiskās sintēzes institūts 50. Pirmais pusgadsimts un nākotnes meti. J. Stradiṇa un O. Pugoviča redakcijā. Rỉga: Zinātne, 2007. 318 lpp.

3. No Grindeḷa lìdz mūsdienām. Apceres par farmācijas tradīcijām un jaunu ārstniecības preparātu meklējumiem Latvijā. J. Stradiṇa sakārt. Rīga: Nordik, 1996. 360 lpp.

4. С. А. Гиллер. Жизнь и научная деятельность. Рига: Зинатне, 1982. 392 с.

5. Stradiņš J. Solomona Hillera mūžs un paliekamais devums zinātnē.//Acta Medico-Historica Rigensia. Vol. 7. Riga: 2005, 271.-272. lpp.

6. Stradiņš J. I. Kalviṇa fenomens. Latvijas ZA Vēstis, A dala, 2007, 61. sēj., Nr. 4.

7. LatvijasOrganiskās sintēzes institūts [tiešsaiste]. [Skatīts 2010.23.VII]. Pieejams: http://www.osi.lv; Akciju sabiedrïba "Grindeks" [tiešsaiste]. [Skatìts 2010.23.VII]. Pieejams: http://www.grindeks.lv; Akciju sabiedrība "Olainfarm" [tiešsaiste]. [Skatìts 2010.23.VII]. Pieejams: http://www.olainfarm.lv

8. Zinātnieks Jānis Polis saṇem WIPO medaḷu. Izglītība un Kultūra, 2009.12.II.

9. Stradiņš J. Remantadīns, tā izgudrotājs Jānis Polis un Organiskās sintēzes institūts. Latvijas Zinātnieks. 2009.24.II.

10. http:/izgudrojumi.lza.lv/izg

11. Bebre L. Gripas laikā remantadīnam cena dubultā. Latvijas Avīze, 2009.27.I.

Rakstā izmantoti materiāli no J. Poḷa personiskā arhīva un izgudrotāja paša atmiņas. 


\title{
Institute of Organic Synthesis and the inventor of the antiviral preparation Remantadine Dr. Jānis Polis (Summary)
}

\author{
By Jānis Stradiņ̌̌
}

In January 2009 the World Intellectual Property Organization (WIPO) in Geneva awarded with its golden medails the leading and most innovative research institution in Latvia - Latvian Institute of Organic Synthesis. A former leading researcher of this Institute Dr. Jānis Polis was honoured by the same medail simultaneusly. This article gives a detailed account about the activities of the institute (founded by Prof. S. A. Hillers in 1957) in developing new medicals, as well as the history of inventing new antiviral preparations of aminoadamantane structure. The history of invention and use of Remantadine (Rimantadine) since 1970-ies and the dramatic fate of its inventor Dr. Jānis Polis has been outlined for the first time. Remantadine a very recognized and effective medical against influenza up to now; it is produced in Latvia ("Olainfarm", "Grindex") and exported to other countries.

Jānis Stradiņš, profesors, Dr. habil. chem., Dr. hist. h.c. stradins@lza.lv 